DOI: $10.6060 / \mathrm{mhc} 150769 \mathrm{~b}$

\title{
Synthesis of New Porphyrin Trimers via Buchwald-Hartwig Amination Reaction
}

\author{
Vladimir S. Tyurin, ${ }^{a}$ Elena A. Mikhalitsyna, ${ }^{a}$ Alexandr S. Semeikin, ${ }^{\mathrm{c}}$ \\ and Irina P. Beletskayaa ${ }^{\mathrm{a}, @}$ \\ ${ }^{a}$ A.N. Frumkin Institute of Physical Chemistry and Electrochemistry, Russian Academy of Sciences, 119071 Moscow, Russian \\ Federation \\ ${ }^{\mathrm{b}}$ M.V. Lomonosov Moscow State University, Chemistry Department, 119992 Moscow, Russian Federation \\ 'Ivanovo State University of Chemistry and Technology, 153000 Ivanovo, Russian Federation \\ ${ }^{\circledR}$ Corresponding author E-mail:beletska@org.chem.msu.ru
}

\begin{abstract}
Two types of the novel porphyrin trimers linked by amines were synthesized by the Buchwald-Hartwig amination reaction of zinc complex of 5-(4-bromophenyl)- $\beta$-octaalkylporphyrin with zinc 5,15-di(4-aminophenyl)-10,20-dimesitylpor-

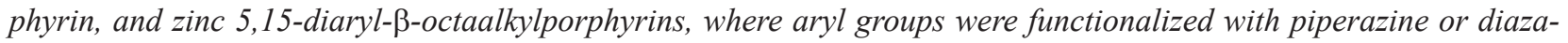
18-crown-6 ether. One type of trimers was bridged by one nitrogen atom of diphenylamine and another type of trimers was linked through two different nitrogene atoms of the cyclic diamines. Each type of the trimers has required specific catalyst composition varying in the ligands for catalytic palladium complex: BINAP and DavePhos correspondingly. The highest $75 \%$ yield was achieved for the piperazine linked trimer. UV-Vis spectroscopic investigations of the synthesized compounds were carried out and showed that the observed spectra of the trimers consist of the spectra sum of their porphyrin components. Thus the trimers have shown negligible interchromophore interaction in both ground and excited states. The geometry of the trimer bridged by diphenylamine was optimized by molecular mechanics $M^{+}$ method showing angled structure with the distance between centers of the macrocycles of 16.86 A. The interaction of the chromophores should be weak on such a distance, and there is no conjugation of electron systems of chromophores due to the orthogonal orientation of the bridging benzene rings relative to the tetrapyrrole plane. These results of the geometry calculations well correspond to the spectroscopic observations.
\end{abstract}

Keywords: Porphyrin trimer, oligoporphyrin, interchromophore interaction, aminoporphyrin, Buchwald-Hartwig amination, cyclic diamine, diazacrown ether.

\section{Синтез новых порфириновых тримеров с помощью реакции аминирования Бухвальда-Хартвига}

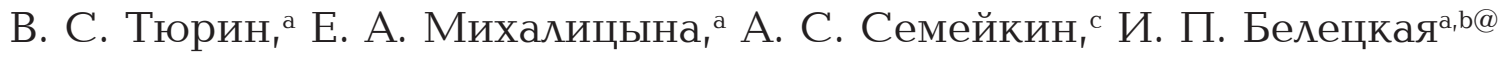

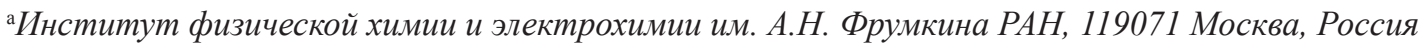 \\ ${ }^{\mathrm{b}}$ Химический факультет МГУ им. М.В. Ломоносова, 119992 Москва, Россия \\ 'Ивановский государственный химико-технологический университет, 153000 Иваново, Россия \\ @E-mail:beletska@org.chem.msu.ru
}

Два типа новых порфириновых тримеров с аминовыми мостиковыми группами были синтезированы с помощью реакиии аминирования Бухвальда-Хартвига между цчинковыми комплексами 5-(4-бромфенил)$\beta$-октаалкилпорфирина и 5,15-ди(4-аминофенил)-10,20-димезитилпорфирина и 5,15-диарил- $\beta$-октаалкилпорфиринов, в которых арильные группы функиионализированы пиперазином или диаза-18-краун-6-эфиром. Один тип тримеров использует в качестве связывающего мостика один атом азота дифениламина, а другой тип тримеров связан через два различных атома азота ичиклческих диаминов. Для получения каждого типа тримеров требуется специифический состав катализатора, отличающегося используемыми лигандами для каталитического палладиевого комплекса: BINAP и DavePhos, соответственно. Наиболее высокий выход $75 \%$ 
был достигнут для тримера, связанного пиперазиновым мостиком. Были проведены исследования электронной спектроскопии поглощения синтезированных соединений, которые показали, что наблюдаемые спектры тримеров состоят из суммы спектров составляющих их порфириновых компонентов. Таким образом, взаимодействие между хромофорами в тримерах незначительно как в основном, так и в возбужденном состояниях. Геометрия тримера, связанного дифениламиновым мостиком, была оптимизирована методом молекулярной механики $\mathrm{MM}^{+}$, и было показано, что структура тримера угловая с расстоянием между центрами макроциклов 16,86 А. Взаимодействие хромофоров на таком расстоянии должно быть слабое, и, кроме того, отсутствует сопряжение электронных систем хромофоров из-за ортогональной ориентации мостиковых бензольных колец по отношению к тетрапиррольной плоскости. Данные результаты расчетов геометрии хорошо согласуются с наблюдаемыми электронными спектрами поглощения.

Ключевые слова: Тример порфирина, олигопорфирин, взаимодействие хромофоров, аминопорфирин, аминирование по Бухвальду-Хартвигу, циклический диамин, диазакраун-эфир.

\section{Introduction}

Multiporphyrins are of increasing interest due to their special electronic properties arising from the interaction of aromatic systems of the tetrapyrrole macrocycles. Such interactions give rise to the new properties inherent in this ensemble which are not the simple sum of components. The nature of the interactions depends on a relative spatial positioning, geometry, rigidity and type of the bridges connecting porphyrinic cycles. Conjugation conductive groups are of special interest. Expanded $\pi$-conjugation leads to unusual electronic properties applicable in molecular electronic devices, ${ }^{[1-4]}$ photon tunnels, ${ }^{[5]}$ multispin molecules with magnetic properties, ${ }^{[6]}$ devices for the information storage, ${ }^{[7]}$ nonlinear optical (NLO) materials, ${ }^{[8,9]}$ and accompanied to that increased long-wave absorbance is important in sensitizers for photodynamic therapy (PDT ${ }^{[10]}$ and solar cells. ${ }^{[11]}$

Numerous oligoporphyrins with a large variety of connecting fragments were reported. ${ }^{[12]}$ Among them just a few types of relatively short linkers were explored. The shorter distance between tetrapyrrole aromatic sytems means the higher degree of their interaction. But the distance is only one of the numerous parameters which can tune the interchromophore interaction. Mutual arrangement, angles between tetrapyrrole planes, nature of the bridges linking porphyrins play an important role. ${ }^{[13]}$ The strongest interaction was with $\pi$-conjugation conducting linkers. These types of linkers are easy to insert via the well developed catalytic cross-coupling methodology such as Heck, Suzuki, and Sonogashira reactions. ${ }^{[12,14-16]}$ Among them acetylene, phenylene, and their combinations were frequently used as linkers in oligoporphyrins. Acetylene groups were used as the most effective conductors of $\pi$-conjugation. ${ }^{[3,4,15]}$ The very short distance and high conjugation lead to the strong interaction which practically combine all porphyrins to the united aromatic systems. The Sonogashira reaction of the bromoporphyrin with the ethyne synton provides a simple way to obtain oligoporphyrins linked with ethyne and also with diarylethyne linker. The latter is considerably longer and does not conduct conjugation due to the orthogonal orientation of the benzene rings to porphyrin plane. Both allow almost free rotation of the porphyrin units. The Suzuki reaction is a simple way to synthesize oligoporphyrins with phenylene linker which is also nonconjugated but more rigid than ethyne contained linkers. The above linkers are linear holding porphyrins along one axis. Anthracene and similar bridges were used for creating cofacial porphyrin dimers resembling special pair. ${ }^{[2]}$ For modelling natural photosynthesis interesting trimers combining cofacial and linear collocation of porphyrin units were synthesized by the Suzuki reaction. ${ }^{[17]}$ There were used two types of nonconjugative binding: biphenylene, anthracene, dibenzothiophene links for cofacial arrangement and direct meso-meso linking of porphyrins and phenylene link for linear layout. All these relatively short linkers have allowed the rapid and efficient energy transfer in excited state despite the lack of conjugation. ${ }^{[3,4,17,18]}$ The Heck and Stille reactions allow to obtain angled and rigid oligoporphyrins with the ethylene and diphenylethylene linkers. ${ }^{[12,19]}$ Another type of linking methodology via 1,2,3-triazole was performed by catalytic 1,3-dipolar cycloaddition which is so called 'click' reaction. ${ }^{[20]}$ 1,4-Diphenyl-1,2,3-triazole group is a rigid angled linker providing effective electronic communication of the porphyrin units in the excited state which was investigated by femtosecond spectroscopy clearly demonstrating very interesting coherent phenomenon. ${ }^{[21]}$

Among various linkers amino group is of special interest as it is capable to coordinate metal cations, imparting porphyrinic molecules additional bonding centers. It is necessary to emphasize, that metalloporphyrins with amino groups contain two opposite types of bonding centers: electrophilic metallocenter and nucleophilic nitrogen center. Such combination provides these molecules with ability to self-assembly, and enriches design opportunities of supramolecular ensembles, amplifies receptor properties. Besides by means of amine groups as strong donor substituents it is possible to influence electronic density of porphyrin macrocycle and, consequently, photophysical characteristics. meso-Diarylamino substituted porphyrins were shown to be the best sensitizers for the dye-sensitized solar cells. ${ }^{[22]}$ Among oligoporphyrins one of the highest efficiencies were achieved with porphyrin dimers linked by aminophenyl groups attached to 1,3,5-triazole heterocycle. ${ }^{[23]}$ Earlier we have investigated synthesis of the bisporphyrins linked by diphenylamine and various diamine linkers and have showed their abilities for supramolecular assembly.

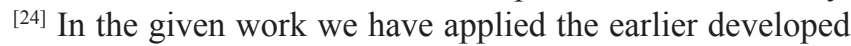
approaches to a synthesis of new porphyrin trimers linked with diphenylamine group and cyclic diamines. 


\section{Experimental}

Materials. 1,4-Dioxane was distilled and dried over sodium under atmosphere of $\mathrm{Ar}$. $\mathrm{CH}_{2} \mathrm{Cl}_{2}$ was distilled over $\mathrm{CaH}_{2}$, $\mathrm{CHCl}_{3}$ was distilled over $\mathrm{P}_{2} \mathrm{O}_{5}$ and was freed of acids by stirring over $\mathrm{K}_{2} \mathrm{CO}_{3}$. Methanol was distilled over magnesium turnings. The starting materials were generally used as received (Aldrich). 5-(4-Bromophenyl)-2,3,7,8,12,18-hexamethyl-13,17-di(n-pentyl) porphyrin zinc(II) (ZnPPhBr), 5,15-bis[4'-(1,4,10,13-tetraoxa-7,16diazacyclooctadec-7-yl)-phenyl)]-3,7,13,17-tetramethyl-2,8,12,18tetra(n-pentyl)porphyrin zinc(II) $\mathrm{ZnP}(\mathrm{PhDiaza} 18 \mathrm{C} 6)_{2},{ }^{[25]}$ 5,15-di(4aminophenyl)-10,20-dimesitylporphyrin $\left(\mathrm{H}_{2} \mathrm{PMes}_{2}\left(\mathrm{PhNH}_{2}\right)_{2}\right),{ }^{[20]}$ and 5-(4-aminophenyl)-10,15,20-trimesitylporphyrin $\mathrm{H}_{2} \mathrm{PMes}_{3} \mathrm{PhNH}_{2}{ }^{[26]}$ were obtained as earlier reported.

Measurements. ${ }^{1} \mathrm{H}(600 \mathrm{MHz})$ and ${ }^{13} \mathrm{C}(150 \mathrm{MHz}) \mathrm{NMR}$ spectra were recorded on Bruker Avance 600 spectrometer at room temperature and referenced to the residual protons of solvent $\left(\mathrm{CDCl}_{3}: \delta_{\mathrm{H}} 7.28 \mathrm{ppm}\right)$. MALDI-TOF mass spectra were recorded on an Ultraflex MALDI TOF Bruker Daltonics spectrometer with dithranol matrix. UV-Visible spectra were recorded on a Cary-100 Varian spectrometer. All reactions were performed under argon atmosphere and monitored by TLC Macherey-Nagel Alugram SIL G/ UV254 silica gel $60 \mathrm{UV}_{254}\left(\mathrm{CH}_{2} \mathrm{Cl}_{2}-\mathrm{MeOH}\right)$. Column chromatography was performed on silica gel Macherey-Nagel 60 0.04-0.063 (230-400 mesh). Molecular mechanics $\mathrm{MM}^{+}$calculations were performed by using HyperChem 7.51 program. ${ }^{[27]}$

Zinc(II) 5,15-di(4-aminophenyl)-10,20-dimesitylporphyrin $\mathrm{ZnPMes}_{2}\left(\mathrm{PhNH}_{2}\right)_{2}$. 5,15-Di(4-aminophenyl)-10,20-dimesitylporphyrin $\mathrm{H}_{2} \mathrm{PMes}_{2}\left(\mathrm{PhNH}_{2}\right)_{2}(353 \mathrm{mg}, 0.48 \mathrm{mmol})$ was dissolved in dichloromethane $(50 \mathrm{ml}), \mathrm{Zn}(\mathrm{OAc})_{2} \cdot 2 \mathrm{H}_{2} \mathrm{O}(2.10 \mathrm{~g}, 9.6 \mathrm{mmol})$ was added, and reaction mixture was stirred for $24 \mathrm{hrs}$ at room temperature. Then the solution was filtered and evaporated in vacuo, and the residue was passed through silica gel column. The second fraction was evaporated to give $0.341 \mathrm{mg}(90 \%)$ of the green-violet crystals of $\mathrm{ZnPMes}_{2}\left(\mathrm{PhNH}_{2}\right)_{2} .^{1} \mathrm{H} \mathrm{NMR}\left(600 \mathrm{MHz}, \mathrm{CDCl}_{3}, 298 \mathrm{~K}\right)$ $\delta_{\mathrm{H}}$ ppm: $8.85(4 \mathrm{H}, \mathrm{d}, J=4.35 \mathrm{~Hz}, \beta-\mathrm{H}), 8.65(4 \mathrm{H}, \mathrm{d}, J=4.46 \mathrm{~Hz}$, $\beta-\mathrm{H}), 7.98(4 \mathrm{H}, \mathrm{d}, J=7.55 \mathrm{~Hz}, \mathrm{Ar}-\mathrm{H}), 7.41(4 \mathrm{H}, \mathrm{s}, \mathrm{Ar}-\mathrm{H}), 7.05(4 \mathrm{H}$, d, $J=7.78 \mathrm{~Hz}, \mathrm{Ar}-\mathrm{H}), 4.06\left(4 \mathrm{H}\right.$, br s, $\left.\mathrm{NH}_{2}\right), 2.61\left(6 \mathrm{H}, \mathrm{s}, \mathrm{CH}_{3}\right), 1.86$ $\left(12 \mathrm{H}, \mathrm{s}, \mathrm{CH}_{3}\right)$. UV-Vis $\left(\mathrm{CH}_{2} \mathrm{Cl}_{2}\right) \lambda \mathrm{nm}(\lg \varepsilon)$ : 424 (5.6), 551 (4.34), 593 (3.73). Mass spectrum (MALDI TOF) $\mathrm{m} / \mathrm{z}: 790.28[\mathrm{M}]^{+}$for $\left[\mathrm{C}_{50} \mathrm{H}_{42} \mathrm{~N}_{6} \mathrm{Zn}\right]$.

Trimer $\mathrm{ZnPMes}_{2}(\mathrm{PhNH})_{2}-(\mathrm{ZnPPh})_{2} . \quad \mathrm{Pd}(\mathrm{dba})_{2}(3.16 \mathrm{mg}$, $\left.5.4 \cdot 10^{-3} \mathrm{mmol}, 10 \mathrm{~mol} \%\right),( \pm)$ BINAP $\left(6.91 \mathrm{mg}, 5.69 \cdot 10^{-3} \mathrm{mmol}\right.$, $20 \mathrm{~mol} \%)$ and $\mathrm{NaO}^{t} \mathrm{Bu}\left(7.5 \mathrm{mg}, 7.8 \cdot 10^{-2} \mathrm{mmol}\right)$ were placed in a dried, resealable $10 \mathrm{ml}$ round-bottom flask with magnetic stirrer, which was backfilled with argon. Then $\mathrm{ZnPMes}_{2}\left(\mathrm{PhNH}_{2}\right)_{2}(21 \mathrm{mg}$, $0.027 \mathrm{mmol})$ and $\mathrm{ZnPPhBr}(42 \mathrm{mg}, 0.056 \mathrm{mmol})$ were dissolved in dioxane $(1 \mathrm{ml})$ added to the flask, and the flask was sealed and heated to reflux with stirring for $24 \mathrm{hrs}$. The reaction mixture was then cooled to room temperature, taken up in dichloromethane $(10 \mathrm{~mL})$, filtered, and concentrated in vacuo. The crude product was purified by column chromatography on silica gel using elution by dichloromethane/petroleum ether $3: 2$ with $1-2 \% \mathrm{MeOH}$ and $0.1-0.2 \%$ aqueous ammonia. The first fraction contained starting unreacted $\mathrm{ZnPPhBr}$ and the second fraction contained $12 \mathrm{mg}(21 \%)$ of the major compound $\mathrm{ZnPMes}_{2}(\mathrm{PhNH})_{2}-(\mathrm{ZnPPh})_{2}$ have isolated as a red solid. ' ${ }^{1} \mathrm{H}$ NMR (600 MHz, $\left.\mathrm{CDCl}_{3}, 298 \mathrm{~K}\right) \delta_{\mathrm{H}}$ ppm: $10.04(4 \mathrm{H}, \mathrm{s}$, 10,20-H), 9.76 (2H, s, 15-H), $9.15(4 \mathrm{H}, \mathrm{d}, J=4.59 \mathrm{~Hz}, \beta-\mathrm{H}), 8.89$ $(4 \mathrm{H}, \mathrm{d}, J=4.59 \mathrm{~Hz}, \beta-\mathrm{H}), 8.30(4 \mathrm{H}, \mathrm{d}, J=8.17 \mathrm{~Hz}, \mathrm{Ar}-\mathrm{H}), 8.05(4 \mathrm{H}$, d, $J=8.11 \mathrm{~Hz}$, Ar-H), $7.78(4 \mathrm{H}, \mathrm{d}, J=8.17 \mathrm{~Hz}, \mathrm{Ar}-\mathrm{H}), 7.74(4 \mathrm{H}, \mathrm{d}$, $J=8.11 \mathrm{~Hz}, \mathrm{Ar}-\mathrm{H}), 7.34(4 \mathrm{H}, \mathrm{s}, \mathrm{Mes}-\mathrm{H}), 3.92(8 \mathrm{H}, \mathrm{t}, J=7.69 \mathrm{~Hz}$, $\left.13,17-\mathrm{CH}_{2}\left(\mathrm{CH}_{2}\right)_{3} \mathrm{CH}_{3}\right), 3.57\left(12 \mathrm{H}, \mathrm{s}, 3,7-\mathrm{CH}_{3}\right), 3.56\left(12 \mathrm{H}, \mathrm{s}, 2,8-\mathrm{CH}_{3}\right)$, $2.71\left(12 \mathrm{H}, \mathrm{s}, 12,18-\mathrm{CH}_{3}\right), 2.29-2.24\left(8 \mathrm{H}, \mathrm{m}, 13,17-\mathrm{CH}_{2} \mathrm{CH}_{2} \mathrm{CH}_{2} \mathrm{CH}_{2} \mathrm{CH}_{3}\right)$, $1.93\left(6 \mathrm{H}, \mathrm{s}, \mathrm{CH}_{3}\right), 1.79-1.74\left(8 \mathrm{H}, \mathrm{m}, 13,17-\mathrm{CH}_{2}^{2} \mathrm{CH}_{2}^{2} \mathrm{CH}_{2}^{2} \mathrm{CH}_{2}^{2} \mathrm{CH}_{3}^{3}\right)$, $1.60-1.57\left(8 \mathrm{H}, \mathrm{m}, 13,17-\mathrm{CH}_{2} \mathrm{CH}_{2} \mathrm{CH}_{2} \mathrm{CH}_{2} \mathrm{CH}_{3}\right), 1.54(24 \mathrm{H}, \mathrm{s}$, $\left.\mathrm{CH}_{3}\right), 1.02\left(6 \mathrm{H}, \mathrm{t}, J=7.20 \mathrm{~Hz}, 13,17-\mathrm{CH}_{2} \mathrm{CH}_{2} \mathrm{CH}_{2} \mathrm{CH}_{2} \mathrm{CH}_{3}\right) \cdot{ }^{13} \mathrm{C}$ NMR $\left(150 \mathrm{MHz}, \mathrm{CDCl}_{3}, 298 \mathrm{~K}\right) \delta_{\mathrm{C}} \mathrm{ppm}: 150.56,149.93,148.19$, $147.95,147.61,147.14,141.29,138.38,138.13,136.05,135.67$,
$134.13,132.45,130.71,127.68,117.53,115.45,97.21,96.45$ $32.94,32.39,29.70,26.50,22.79,21.67,15.77,14.16,12.18,11.63$. UV-Vis $\left(\mathrm{CH}_{2} \mathrm{Cl}_{2}\right) \lambda \mathrm{nm}$ (lge): 406 (5.18), 424 (4.8), 536 (4.00), 570 (4.02). Mass spectrum (MALDI TOF) $m / z: 2137.09[\mathrm{M}+3 \mathrm{H}]^{+}$for $\left[\mathrm{C}_{134} \mathrm{H}_{137} \mathrm{~N}_{14} \mathrm{Zn}_{3}\right]$.

Trimer $\mathrm{ZnP}(\text { PhPip })_{2}-\left(\mathrm{Zn}{ }_{2} \mathrm{PPh}\right)$. $\mathrm{ZnP}(\mathrm{PhPip})_{2} \quad(37.8 \mathrm{mg}$, $0.037 \mathrm{mmol}), Z \mathrm{ZnPhBr}(55 \mathrm{mg}, 0.073 \mathrm{mmol}), \operatorname{Pd}(\mathrm{dba}),(3.3 \mathrm{mg}$, $0.01 \mathrm{mmol}\left(5.64 \cdot 10^{-3} \mathrm{mmol}, 8 \mathrm{~mol} \%\right)$ ), DavePhos (4.6 mg), $\mathrm{NaO}^{\prime} \mathrm{Bu}$ $(9.8 \mathrm{mg})$ and dioxane $(1 \mathrm{ml})$ were placed in a dried, resealable round-bottom flask with magnetic stirrer, which was backfilled with argon, sealed and heated to reflux with stirring for $24 \mathrm{hrs}$. The reaction mixture was then cooled to room temperature, filtered and the solvent was evaporated in vacuo. The crude product was purified by column chromatography on silica gel with gradient eluent dichloromethane/methanol 100:0.5 $\div 100: 2$. Yield: $65.5 \mathrm{mg}$ (75\%). ${ }^{1} \mathrm{H}$ NMR $\left(600 \mathrm{MHz}, \mathrm{CDCl}_{3}, 298 \mathrm{~K}\right) \delta_{\mathrm{H}}$ ppm: 10.19-10.11 $(8 \mathrm{H}, \mathrm{m}, 10,15,20-\mathrm{H}), 7.95(8 \mathrm{H}, \mathrm{d}, J=8.01 \mathrm{~Hz}, \mathrm{H}-\mathrm{Ar}), 7.28(8 \mathrm{H}, \mathrm{d}$, $J=8.01 \mathrm{~Hz}, \mathrm{H}-\mathrm{Ar}), 4.02\left(8 \mathrm{H}, \mathrm{m}, 13,17-\mathrm{CH}_{2}\left(\mathrm{CH}_{2}\right)_{3} \mathrm{CH}_{3}\right), 3.96(8 \mathrm{H}, \mathrm{m}$, $\left.2,8,12,18-\mathrm{CH}_{2}\left(\mathrm{CH}_{2}\right)_{3} \mathrm{CH}_{3}\right), 3.49\left(24 \mathrm{H}, \mathrm{s}, 2,8,12,18-\mathrm{CH}_{3}\right), 3.04(8 \mathrm{H}$, $\left.\mathrm{s}, \mathrm{CH}_{2}\right), 2.84\left(8 \mathrm{H}, \mathrm{s}, \mathrm{CH}_{2}\right), 2.57\left(12 \mathrm{H}, \mathrm{s}, 3,7-\mathrm{CH}_{3}\right), 2.55(12 \mathrm{H}, \mathrm{s}, 3,7-$ $\left.\mathrm{CH}_{3}\right), 2.23-2.17\left(16 \mathrm{H}, \mathrm{m}, 2,8,12,18,13,17-\mathrm{CH}_{2} \mathrm{CH}_{2} \mathrm{CH}_{2} \mathrm{CH}_{2} \mathrm{CH}_{3}\right)$, 1.77-1.69 (16H, m, 2,8,12,18,13,17- $\left.\mathrm{CH}_{2} \mathrm{CH}_{2} \mathrm{CH}_{2} \mathrm{CH}_{2} \mathrm{CH}_{3}\right), 1.60$ $1.52\left(16 \mathrm{H}, \mathrm{m}, 2,8,12,18,13,17-\mathrm{CH}_{2} \mathrm{CH}_{2} \mathrm{CH}_{2} \mathrm{CH}_{2} \mathrm{CH}_{3}\right), 1.01-0.95$ $\left(24 \mathrm{H}, \mathrm{m}, 2,8,12,18,13,17-\mathrm{CH}_{2} \mathrm{CH}_{2} \mathrm{CH}_{2} \mathrm{CH}_{2} \mathrm{CH}_{3}\right)$. UV-Vis $\left(\mathrm{CH}_{2} \mathrm{Cl}_{2}\right)$ $\lambda \mathrm{nm}(\lg \varepsilon): 407$ (4.77), 536 (3.54), 571 (3.45). Mass spectrum (MALDI TOF) $m / z: 2372.20[\mathrm{M}]^{+}$for $\left[\mathrm{C}_{148} \mathrm{H}_{180} \mathrm{~N}_{16} \mathrm{Zn}\right]^{+}$.

Trimer $\mathrm{ZnP}(\text { PhDiaza18C6) })_{2}(\mathrm{ZnPPh})_{2}$. $\mathrm{ZnP}(\mathrm{PhDiaza} 18 \mathrm{C} 6)_{2}$ (15.5 mg, $0.011 \mathrm{mmol}$ ), ZnPPhBr (17 mg, $0.022 \mathrm{mmol}$ ), Pd(dba) (1.03 mg, $\left.1.8 \cdot 10^{-3} \mathrm{mmol}, 8 \mathrm{~mol} \%\right)$, DavePhos $\left(1.4 \mathrm{mg}, 3.6 \cdot 10^{-3} \mathrm{mmol}\right.$, $16 \mathrm{~mol} \%), \mathrm{NaO}^{t} \mathrm{Bu}(2.96 \mathrm{mg}, 0.031 \mathrm{mmol})$ and dioxane $(0.5 \mathrm{ml})$ were placed in a dried, resealable round-bottom flask with magnetic stirrer, which was backfilled with argon, sealed and heated to reflux with stirring for $24 \mathrm{hrs}$. The reaction mixture was then cooled to room temperature, filtered and the solvent was evaporated in vacuo. The crude product was purified by column chromatography on silica gel with gradient eluent dichloromethane/ methanol 100:0.5 $\div 100: 2$. Yield: $8.1 \mathrm{mg}(27 \%)$. ${ }^{1} \mathrm{H}$ NMR $(600$ $\left.\mathrm{MHz}, \mathrm{CDCl}_{3}, 298 \mathrm{~K}\right) \delta_{\mathrm{H}}$ ppm: $10.13-9.91(8 \mathrm{H}, \mathrm{m}, 10,15,20-\mathrm{H})$, 7.79 (8H, m, H-Ar), 6.91 (8H, m, H-Ar), 3.98 (16H, m, 2,8,12, $\left.18,13,17-\mathrm{CH}_{2}\left(\mathrm{CH}_{2}\right)_{3} \mathrm{CH}_{3}\right), 3.86\left(16 \mathrm{H}, \mathrm{m},\left(\mathrm{CH}_{2} \mathrm{~N}\right)_{8}\right), 3.73(32 \mathrm{H}, \mathrm{m}$, $\left.\left(\mathrm{CH}_{2} \mathrm{O}\right)_{16}\right), 3.59\left(12 \mathrm{H}, \mathrm{s}, 3,7-\mathrm{CH}_{3}\right), 3.52\left(12 \mathrm{H}, \mathrm{s}, 2,8-\mathrm{CH}_{3}\right), 2.60$ $\left(12 \mathrm{H}, \mathrm{s}, 2,8,12,18-\mathrm{CH}_{3}\right), 2.55\left(12 \mathrm{H}, \mathrm{s}, 13,17-\mathrm{CH}_{3}\right), 2.44(8 \mathrm{H}, \mathrm{m}$, $\left.13,17-\mathrm{CH}_{2} \mathrm{CH}_{2} \mathrm{CH}_{2} \mathrm{CH}_{2} \mathrm{CH}_{3}\right), 2.26\left(8 \mathrm{H}, \mathrm{m}, 2,8,12,18-\mathrm{CH}_{2} \mathrm{CH}_{2} \mathrm{CH}_{2}\right.$ $\left.\mathrm{CH}_{2} \mathrm{CH}_{3}\right), 1.74\left(16 \mathrm{H}, \mathrm{m}, 2,8,12,18-13,17-\mathrm{CH}_{2} \mathrm{CH}_{2} \mathrm{CH}_{2} \mathrm{CH}_{2} \mathrm{CH}_{3}\right)$, $1,55\left(16 \mathrm{H}, \mathrm{m}, 2,8,12,18-13,17-\mathrm{CH}_{2} \mathrm{CH}_{2} \mathrm{CH}_{2} \mathrm{CH}_{2} \mathrm{CH}_{3}\right), 0.98(12 \mathrm{H}, \mathrm{t}$, $\left.J=7.32 \mathrm{~Hz}, 13,17-\mathrm{CH}_{2} \mathrm{CH}_{2} \mathrm{CH}_{2} \mathrm{CH}_{2} \mathrm{CH}_{3}\right), 0.98(12 \mathrm{H}, \mathrm{t}, J=7.32 \mathrm{~Hz}$, $\left.2,8,12,18,13,17-\mathrm{CH}_{2} \mathrm{CH}_{2} \mathrm{CH}_{2} \mathrm{CH}_{2} \mathrm{CH}_{3}\right)$. UV-Vis $\left(\mathrm{CH}_{2} \mathrm{Cl}_{2}\right) \lambda \mathrm{nm}$ $(\lg \varepsilon)$ : 406 (5.59), 536 (4.44), 571 (4.35). Mass spectrum (MALDI TOF) $m / z: 2778.46\left[\mathrm{M}+3 \mathrm{H}_{2} \mathrm{O}\right]^{+}$for $\left[\mathrm{C}_{164} \mathrm{H}_{214} \mathrm{~N}_{16} \mathrm{O}_{11} \mathrm{Zn}_{3}\right]^{+}$.

\section{Results and Discussion}

The synthesis of porphyrin trimers bridged by amino group was performed via palladium catalyzed BuchwaldHartwig amination reaction between $p$-aminophenyl and $p$-bromophenyl meso-substituted porphyrin components where amino group replaces bromine atom thus linking two porphyrins together through nitrogen atom of amino group. Recently we have reported on the synthesis of bisporphyrins ${ }^{[24]}$ bridged by the tertiary diarylalkylamine group formed via two sequential couplings of two bromophenylporphyrin molecules with the primary alkylamine. In the current work two primary arylamino groups of the bis (aminophenyl)porphyrin have reacted with two bromophenylporphyrin molecules to give a trimer with 
a secondary diarylamine bridging group. In principle such trimers can be synthesized via two alternative ways (Figure 1): 1) interaction of one bis(aminophenyl)porphyrin building block with two mono(bromophenyl)porphyrin blocks; 2) reaction of one bis(bromophenyl)porphyrin building block with two mono(aminophenyl)porphyrin blocks. The choice was determined by the ease of the precursors synthesis. Both symmetrical 5,15-functionalized porphyrins are easily available by the $[2+2]$ Mc-Donald condensation of dipyrromethane with substituted benzaldehyde. The hardest is the synthesis of unsymmetrical monosubstituted porphyrin. Synthesis of the mono(aminophenyl)porphyrin via mixed condensation has given low yield with hardly separable byproducts (Supporting Information, Figure 1S) whereas the synthesis of meso-mono(bromophenyl) porphyrin was developed ${ }^{[28,29]}$ by the directional way with high yield through condensation of the arylaldehyde with $\beta$-octaalkyl substituted $a, c$-biladiene ${ }^{[30]}$ obtained from the corresponding $\beta$-substituted 2-formylpyrrole and dipyrromethane (Supporting Information, Figure 2S).

Thus 5,15-bis(aminophenyl)porphyrin was synthesized as follows: [2+2] Mc-Donald condensation of mesomesityldipyrromethane ${ }^{[31]}$ with of $p$-nitrobenzaldehyde has given 5,15-bis(p-nitrophenyl)porphyrin. Mesityl substitution was used as sterically hindered mesityl groups were shown to inhibit side reactions of scrambling in a synthesis of unsymmetrically meso substituted porphyrins. ${ }^{[32]}$ Then without isolation nitrophenylporphyrin was reduced with $\mathrm{SnCl}_{2} \cdot 2 \mathrm{H}_{2} \mathrm{O} / \mathrm{HCl}$ in chloroform/acetic acid following treatment with aqueous ammonia to give $\mathrm{H}_{2} \mathrm{PMes}_{2}\left(\mathrm{PhNH}_{2}\right)_{2}{ }^{[20]}$ with $25 \%$ yield over two stages accordingly. It is known that free base porphyrins are not convenient for homogeneous transition metal catalyzed reactions as they can coordinate catalytic metal ions removing them from the catalytic cycle thus inhibiting the reaction. Therefore the free base porphyrins were converted to their zinc complexes by reaction with an excess zinc acetate monohydrate in boiling chloroform for two hours (Supporting Information, Figure 1S). 5-(4-Bromophenyl)2,3,7,8,12,18-hexamethyl-13,17-di(n-pentyl)porphyrin $(\mathrm{ZnPPhBr})$ was prepared (Supporting Information, Figure $2 \mathrm{~S}$ ) as we have earlier reported. ${ }^{[29]}$ Obtained porphyrins are convenient due to their good solubility in nonpolar solvents provided by $\beta$-alkyl substituents in bromoporphyrin and mesityl groups in aminoporphyrins. Different substitution in the tetrapyrrole cores of the porphyrin building blocks is helpful to discriminate porphyrin units in a trimer. Besides, such heterogeneity is useful for the subsequent investigation of processes of energy transfer between tetrapyrrolic macrocycles.

The coupling reaction between aminophenylporphyrin and bromophenylporphyrin was carried out with a palladium catalyst formed from $10 \mathrm{~mol} \% \mathrm{Pd}(\mathrm{dba})$, in a combination with $20 \mathrm{~mol} \mathrm{\%}$ of a diphosphine ligand ( \pm )-2,2'-bis(diphenylphosphino)-1,1'-binaphthyl ((rac)-BINAP) with 1.4 eq. of $\mathrm{NaO}^{t} \mathrm{Bu}$ as a base in a boiling dioxane under argon during $24 \mathrm{hrs}$. The choice of catalyst and conditions was based on the results of our previous work of amination of bromophenylporphyrins with various amines. ${ }^{[24,25,33,34]}$ The reaction between 5,15-bis(4-aminophenyl)porphyrin $\mathrm{ZnPMes}_{2}\left(\mathrm{PhNH}_{2}\right)_{2}$ and 2 equivalents of 5-(4-bromophenyl)porphyrin $\mathrm{ZnPPhBr}$ has led to arylation of both amino groups yielding $21 \%$ of porphyrin trimer $\mathrm{ZnPMes}_{2}(\mathrm{PhNH})_{2}$ $(\mathrm{ZnPPh})_{2}$ (Figure 2).

Two other trimers were synthesized from porphyrin functionalized with cyclic amines such as piperazine and diaza-18-crown-6 ether. Reaction of one equivalent $\mathrm{ZnP}(\mathrm{PhPip})_{2}$ (bispiperazine substituted zinc porphyrin) with two equivalents of $\mathrm{ZnPPhBr}$ in presence of monophosphine ligand 2-(dicyclohexylphosphino)-2'-(N,N-dimethylamino) biphenyl (DavePhos) has led to the formation of trimer $\mathrm{ZnP}(\mathrm{PhPip})_{2}-(\mathrm{ZnPPh})_{2}$ where three porphyrin fragments are linked with two piperazine bridges (Figure 3 ) in an excellent $75 \%$ yield. This is more than twice higher compared to the yield of the corresponding dimer earlier obtained from the monopiperidine substituted porphyrin. ${ }^{[24]}$ The trimer with diazacrown ether as linker was considerably harder to obtain compared to the analogous dimer. ${ }^{[24]}$ Interaction of the porphyrin with two diaza-18-crown-6 ether fragments $\mathrm{ZnP}(\mathrm{PhDiaza} 18 \mathrm{C6})$, and bromoporphyrin $\mathrm{ZnPPhBr}$ has given the trimer $\mathrm{ZnP}(\mathrm{PhDiaza} 18 \mathrm{C} 6)_{2}-(\mathrm{ZnPPh})_{2}$ in $27 \%$ yield which is almost three times lower than for the piperidine linker (Figure 4).

The structure of the porphyrin trimer $\mathrm{ZnPMes}_{2}(\mathrm{PhNH})_{2}$ $(\mathrm{ZnPPh})_{2}$ was confirmed by ${ }^{1} \mathrm{H}$ NMR. Resonances of protons at $\beta$ - and meso-positions of the tetrapyrrole macrocycle and benzene rings of the $\mathrm{ZnPMes}_{2}(\mathrm{PhNH})_{2}-(\mathrm{ZnPPh})_{2}$ were shifted downfield due to the mutual deshielding interaction
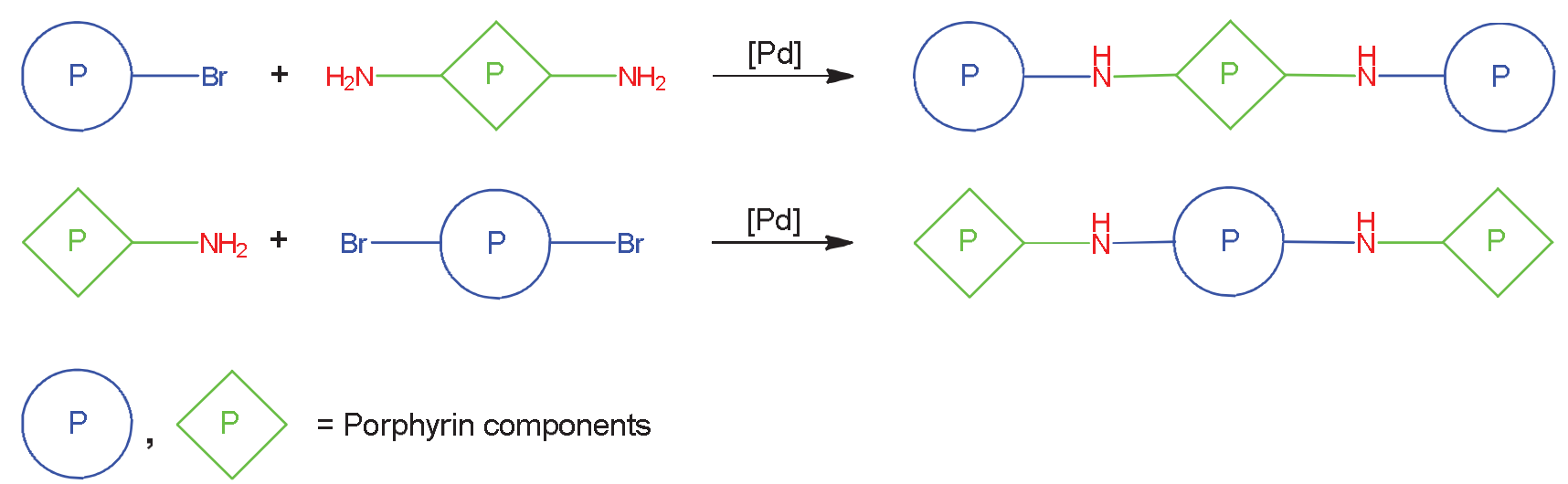

Figure 1. Schemes of synthesis of porphyrin trimers from amino and bromo porphyrin building blocks. 


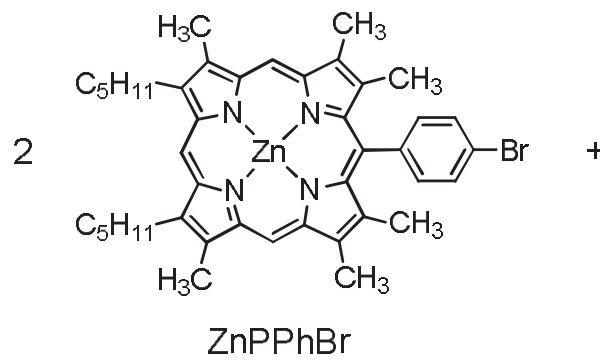

$\mathrm{Pd}(\mathrm{dba})_{2} 10 \mathrm{~mol} \%$ BINAP 20 mol\% 1.4 eq. $\mathrm{NaO}^{\mathrm{t}} \mathrm{Bu}$

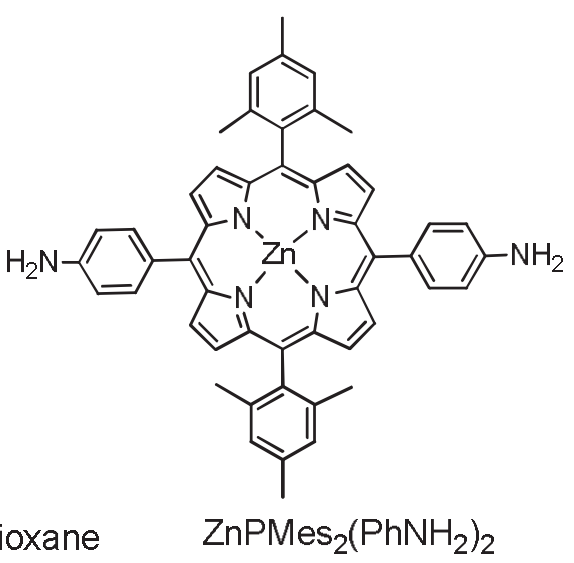

$24 \mathrm{hrs}$

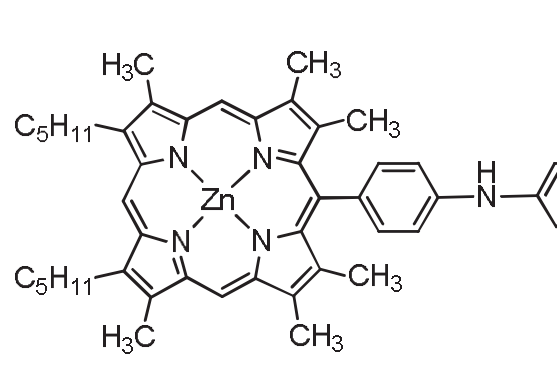
$\mathrm{ZnPMes}_{2}(\mathrm{PhNH})_{2}-(\mathrm{ZnPPh})_{2}$ $21 \%$

Figure 2. Synthesis of the porphyrin trimer.

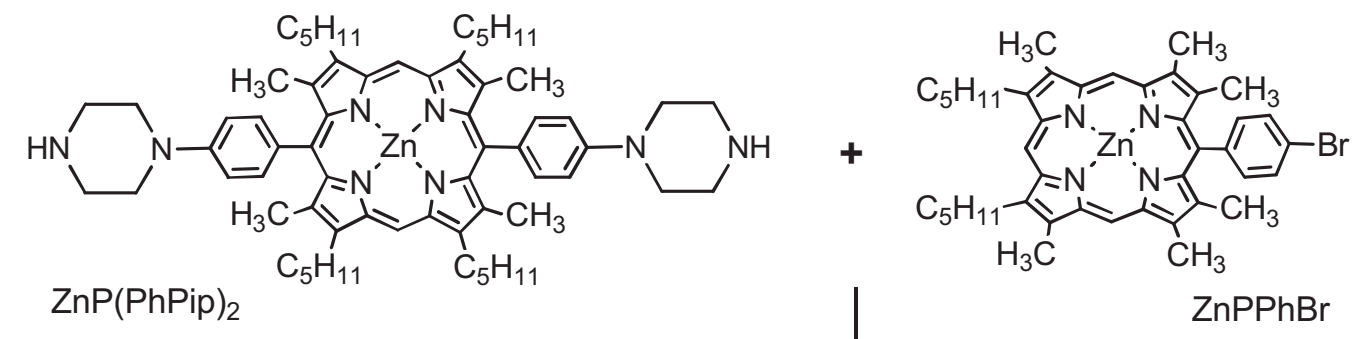

$\mathrm{Pd}(\mathrm{dba})_{2} /$ DavePhos 8/16 mol\%

dioxane, $100{ }^{\circ} \mathrm{C}, 24 \mathrm{~h}$

$\mathrm{NaO}{ }^{t} \mathrm{Bu}$

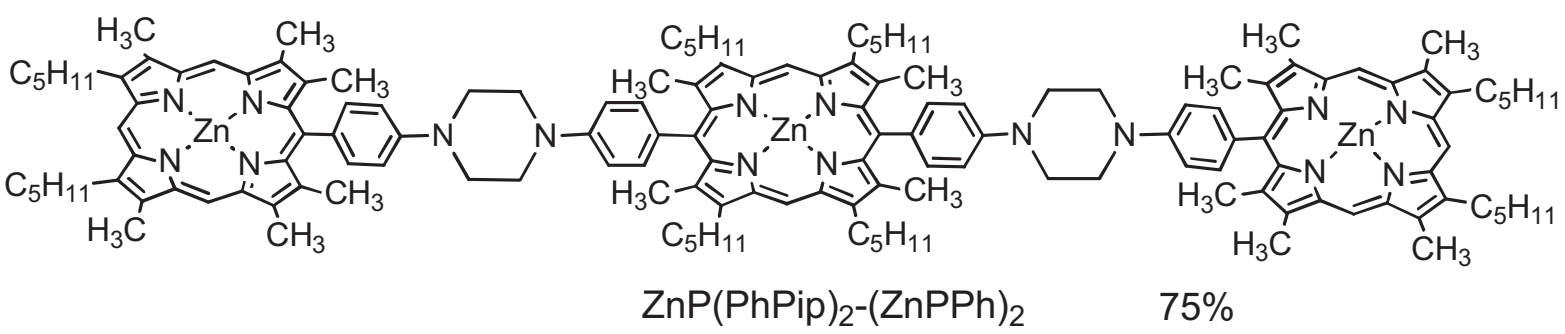

Figure 3. Synthesis of the porphyrin trimer linked by piperazine. 


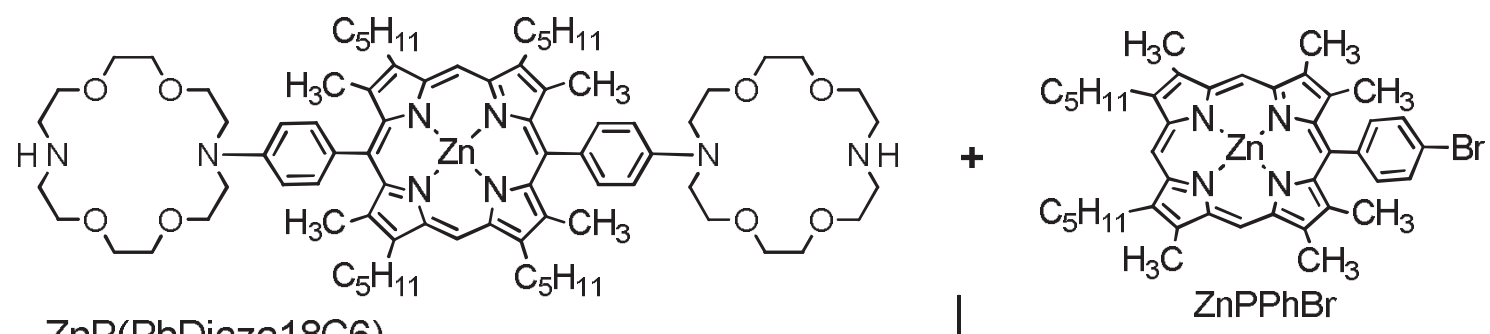

$\mathrm{ZnP}(\mathrm{PhDiaza} 18 \mathrm{C6})_{2}$

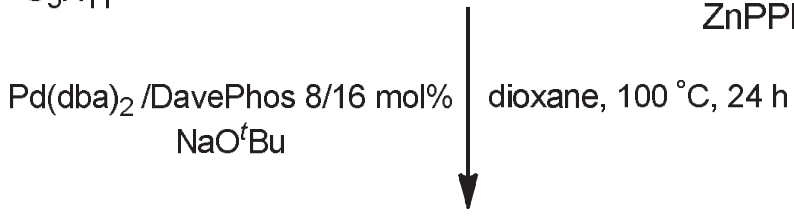

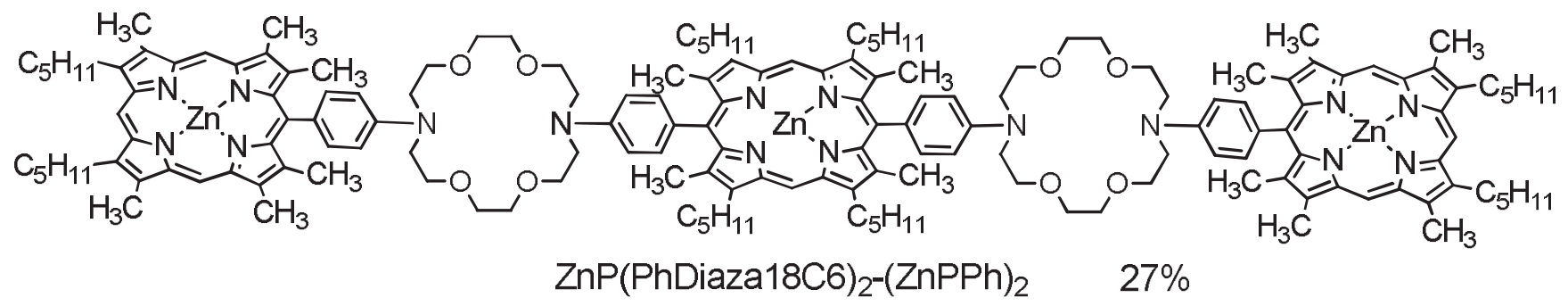

Figure 4. Synthesis of the porphyrin trimer linked by diazacrown ether.

of the porphyrin aromatic systems for $\Delta \delta=0.3(0.24), 0.24$ (0.14), 0.15-0.69 ppm correspondingly (Support, Table 1S). But phenyl protons at $\beta$-position (Support, Figure 3S) were slightly upshifted due to the donor effect of nitrogen atom (instead of bromine). Thus the phenyl protons resulted from bromo component were discriminated shifting in opposite directions. The methyl groups of mesityl substituents were upshifted for 0.68 and $0.32 \mathrm{ppm}$. The proton shifts in both dimers were not so unambiguous. Shifting of $\beta$-protons of dimers was insignificant ( $\sim 0.1 \mathrm{ppm})$. Shifts of $\beta$-protons of amino bridged dimer ( $\left.\mathrm{ZnPMes}_{3} \mathrm{Ph}\right)_{2} \mathrm{NH}$ were downfield and dimer without amino group ( $\left.\mathrm{ZnPMes}_{3} \mathrm{Ph}\right)_{2}$ had an upshift. But the shifts of the protons of bridging benzene rings of amino component were considerable and downfield for all compounds. The oligomers linked by cyclic diamines contained one type of $\beta$-alkylsubsituted tetrapyrrole rings. The meso-protons of the oligomers were shifted downfield whereas phenyl protons were not shifted unidirectionally (Support, Table 2). The $\mathrm{CH}_{2}$ protons of the cyclic diamines were shifted upfield for the piperazine bridged trimer and downfield for diazacrown ether bridged oligomers.

The electronic spectra of the trimer $\mathrm{ZnPMes}_{2}(\mathrm{PhNH})_{2}^{-}$ $(\mathrm{ZnPPh})_{2}$ have revealed the splitting of the Soret band to two components with $\lambda_{\max }=424 \mathrm{~nm}$ and $\lambda_{\text {max }}=406 \mathrm{~nm}$ (Table 1). Their intensity ratio is $2: 1$ which corresponds to the ratio of the two different types of the porphyrin components (one central and two peripheral), and the positions of the Soret bands are also the same as in starting porphyrin building blocks $\mathrm{ZnPMes}_{2}\left(\mathrm{PhNH}_{2}\right)_{2}$ and $\mathrm{ZnPPhBr}$. Thus the observed spectra of the trimer could be just a simple sum of the spectra of two types of porphyrin components. The difference in the positions of the adsorption bands results from the different substitution of the tetrapyrrole macrocycles: one has $\beta$-alkyl substituents and 3 free meso-positions, and another has free $\beta$-positions and meso-mesityl substituents.
Table 1. Electronic spectra of the porphyrin substrates and coupling products.

\begin{tabular}{cll}
\hline & \multicolumn{2}{c}{$\lambda_{\max }, \mathrm{nm}(\lg \varepsilon)$} \\
\cline { 2 - 3 } Compound & \multicolumn{1}{c}{$\begin{array}{c}\text { Soret } \\
\text { band }\end{array}$} & Q bands \\
\hline $\mathrm{H}_{2} \mathrm{PPhBr}$ & $404(5.29)$ & $\begin{array}{l}503(4.21), 537(3.92), \\
571(3.88), 624(3.57)\end{array}$ \\
$\mathrm{ZnPPhBr}$ & $406(5.56)$ & $536(3.98), 572(3.95)$ \\
$\mathrm{ZnPMes}_{2}\left(\mathrm{PhNH}_{2}\right)_{2}$ & $424(5.6)$ & $551(4.34), 593(3.73)$ \\
$\mathrm{ZnPMes}_{2}(\mathrm{PhNH})_{2}-(\mathrm{ZnPPh})_{2}$ & $406(5.18)$ & $536(4.00), 570(4.02)$ \\
$\mathrm{ZnP}(\mathrm{PhPip})_{2}$ & $413(5.02)$ & $542(3.87), 574(3.6)$ \\
$\mathrm{ZnP}(\mathrm{PhPip})_{2}-(\mathrm{ZnPPh})_{2}$ & $407(4.77)$ & $536(3.54), 571(3.45)$ \\
$\mathrm{ZnP}(\mathrm{PhDiaza18C6})_{2}$ & $418(4.57)$ & $545(3.43), 577(3.01)$ \\
$\mathrm{ZnP}(\mathrm{PhDiaza} 18 \mathrm{C} 6)_{2}-(\mathrm{ZnPPh})_{2}$ & $408(4.74)$ & $537(3.59), 571(3.45)$ \\
$\mathrm{ZnP}(\mathrm{PhDiaza} 18 \mathrm{C} 6)_{2}-\mathrm{ZnPPh}$ & $406(5.59)$ & $536(4.44), 571(4.35)$ \\
\hline
\end{tabular}

It is known that the splitting of the Soret band in the multiporphyrins can be a consequence of the excitation coupling ${ }^{[35,36]}$ and reported as characteristic for meso-meso linked porphyrins. ${ }^{[20,37]}$ The geometry of the trimer was optimized by molecular mechanics $\mathrm{MM}^{+}$method (Figure 5). The distance between centers of the macrocycles is 16.86 $\AA$. The interaction of the chromophores is weak on such distance, and there is no conjugation of electron systems of chromophores due to the orthogonal orientation of the bridging benzene rings relatively tetrapyrrole plane. Based on the optimized geometry the calculated value (made by point-dipole approximation $)^{[38]}$ of the splitting for the trimer $(\sim 6 \mathrm{~nm})$ turned out to be three times less than difference between centers of the Soret bands of the trimer porphyrin components $(18 \mathrm{~nm})$. But the conformational freedom of the 


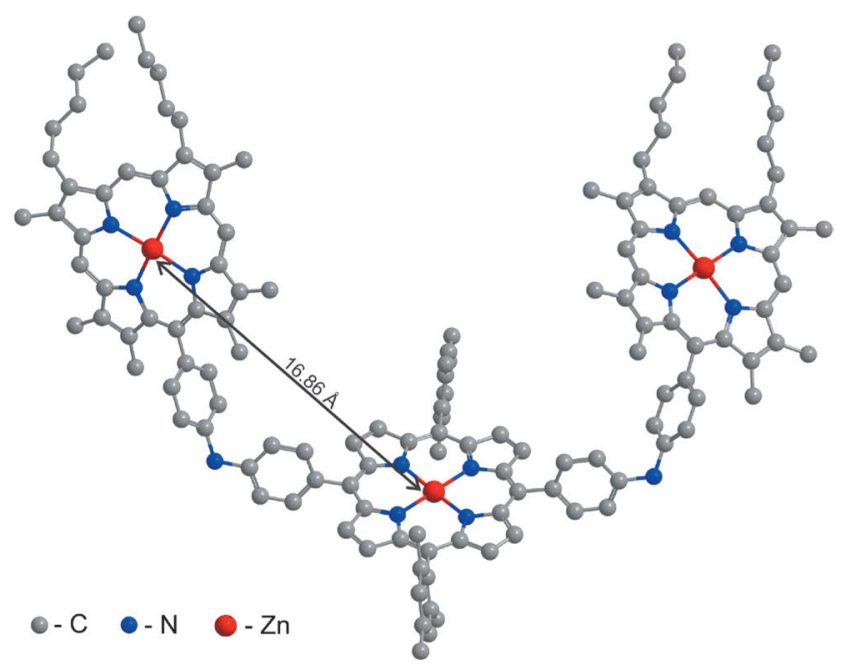

Figure 5. Calculated structure (geometry optimized by molecular mechanics $\mathrm{MM}^{+}$method) of $\mathrm{ZnPMes}_{2}(\mathrm{PhNH})_{2}-(\mathrm{ZnPPh})_{2}$.

trimer could lead to the decreased exciton coupling in the other conformers and broad shape of the two overlapping Soret bands probably didn't allow to reveal the possible splitting.

The distances between centers of the macrocycles in the trimers bridged by piperazine and diazacrown ether are considerably larger. Besides these bridges are even more conformationally flexible. Thus the splitting of the Soret band in these cases should be completely negligible.

\section{Conclusions}

The novel porphyrin trimer compounds were synthesized by Buchwald-Hartwig amination reaction. Yields of the reaction are highly dependent on the substrates. The higher $75 \%$ yield was achieved for piperazine linked trimer. UV-Vis spectroscopic investigations did not reveal interchromophore interaction between porphyrin components in both types of the synthesized porphyrin trimers which can be explained by the conformational freedom of the linkers allowing the variety of relative positions of the monomer components in the trimer. Obtained trimers are interesting as they are linked by the groups capable to coordination with metal cations with the possible formation of the supramolecular assemblies. Especially cyclic piperazine and diazacrown ether linkers are strong chelating ligands. The coordination of metal cations with the trimers could lead to the changes of the mutual position of the porphyrin components and correspondingly to the changes of their electronic communication giving possibilities to control the photophysical properties of the porphyrin trimers. The investigation of the supramolecular coordination of the trimers and their photophysical properties is on the way and will be reported in upcoming publications.

Acknowledgements. This work was supported by Russian Academy of Sciences (Program of Division of chemistry and material science N 5 "Chemistry and physical chemistry of supramolecular systems and atomic clusters").

\section{References}

1. (a) Gust D., Moore T.A., Moore A.L. Acc. Chem. Res. 2001, 34, 40-41; (b) Holten D., Bocian D.F., Lindsey J.S. Acc. Chem. Res. 2002, 35, 57-69; (c) Kim D., Osuka A. Acc. Chem. Res. 2004, 37, 735-745; (d) Aratani N., Osuka A., Cho H.S., Kim D. J. Photochem. Photobiol. C Photochem. Rev. 2002, 3, 25-52; (e) Meier H. Angew. Chem. Int. Ed. 2009, 48, 39113913; (f) Sugiyasu K., Takeuchi M. Chem. Eur. J. 2009, 15, 6350-6362.

2. Harvey P.D., Stern C., Guilard R. Bio-inspired Molecular Devices Based on Systems Found in Photosynthetic Bacteria. In: Handbook of Porphyrin Science, Vol. 11 (Kadish K.M., Smith K.M., Guilard R., Eds.) Singapore: World Scientific, 2011. p. 1-179.

3. Ambroise A., Kirmaier C., Wagner R.W., Loewe R.S., Bocian D.F., Holten D., Lindsey J.S. J. Org. Chem. 2002, 67, 38113826.

4. Punidha S., Ravikanth M. Tetrahedron 2008, 64, 8016-8028.

5. Prathapan S., Johnson T.E., Lindsey J.S. J. Am. Chem. Soc. 1993, 115, 7519-7520.

6. (a) Shultz D.A., Lee H., Gwaltney K.P. J. Org. Chem. 1998, 63, 7584-7585; (b) Brandon E.J., Rogers R.D., Burkhart B.M., Miller J.S. Chem. Eur. J. 1998, 4, 1938-1943; (c) Wynn C.M., Girtu M.A., Sugiura K.-I., Brandon E.J., Manson J.L., Miller J.S., Epstein A.J. Synth. Met. 1997, 85, 1695-1700; (d) Miller J.S., Calabrese J.C., McLean R.S., Epstein A.J. $A d v$. Mater. 2004, 4, 498-501.

7. Hopfield J.J., Onuchic J.N., Beratan D.-N. J. Phys. Chem. 1989, 93, 6350-6357.

8. Calvete M., Yang G.Y., Hanack M. Synth. Met. 2004, 141, 231-243.

9. Senge M.O., Fazekas M., Notaras E.G.A., Blau W.J., Zawadzka M., Locos O.B., Mhuircheartaigh E.M.N. Adv. Mater. 2007, 19, 2737-2774.

10. Cunha A.C., Gomes A.T.P.C., Ferreira V.F., Souza M.C.B.V., Neves M.G.P.M.S., Tome A.S., Silva A.M.S., Cavaleiro J.A.S. Synthesis 2010, 510-514.

11. Diau E.W.-G., Li L.-L. Porphyrin-Sensitized Solar Cells. In: Handbook of Porphyrin Science (Ferreira G.S., Kadish K.M., Guilard R., Smith K.M., Eds.) Singapore: World Scientific, 2014, Vol. 28, p. 279-317.

12. (a) Beletskaya I.P., Tyurin V.S., Uglov A., Stern C., Guilard R. Survey of Synthetic Routes for Synthesis and Substitution in Porphyrins. In: Handbook of Porphyrin Science (Kadish K.M., Smith K.M., Guilard R., Eds.) Singapore: World Scientific, 2012, Vol. 23, p. 81-279; (b) Aratani N., Osuka A. Synthetic Strategies toward Multiporphyrinic Architectures. In: Handbook of Porphyrin Science (Kadish K.M., Smith K.M., Guilard R., Eds.) Singapore: World Scientific, 2012, Vol. 1, p. $1-132$.

13. Harvey P.D. Recent Advances in Free and Metalated Multiporphyrin Assemblies and Arrays: a Photophysical Behavior and Energy Transfer Perspective. In: The Porphyrin Handbook (Kadish K.M., Guilard R., Smith K.M., Eds.), Amsterdam: Academic Press, 2003, Vol. 18, p. 63-250.

14. Senge M.O., Shaker Y.M., Pintea M., Ryppa C., Hatscher S.S., Ryan A., Sergeeva Y. Eur. J. Org. Chem. 2010, 237-258.

15. Song H.-E., Kirmaier C., Diers J.R., Lindsey J.S., Bocian D.F., Holten D. J. Phys. Chem. B 2009, 113, 54-63.

16. (a) Taylor P.N., Anderson H.L. J. Am. Chem. Soc. 1999, 121, 11538-11545; (b) Nakamura K., Fujimoto T., Takara S., Sugiura K.-I., Miyasaka H., Ishii T., Yamashita M., Sakata Y. Chem. Lett. 2003, 32, 694-695; (c) Lin V.S., DiMagno S.G., Therien M.J. Science 1994, 264, 1105-1111.

17. Camus J.-M., Harvey P.D., Guilard R. Macroheterocycles 2013, 6, 13-22. 
18. Wagner R.W., Johnson T.E., Li F., Lindsey J.S. J. Org. Chem. 1995, 60, 5266-5273.

19. (a) Lee Y., Liang Y., Yu L. Synlett 2006, 2879-2893; (b) Frampton M.J., Akdas H., Cowley A.R., Rogers J.E., Slagle J.E., Fleitz P.A., Drobizhev M., Rebane A., Anderson H.L. Org. Lett. 2005, 7, 5365-5368.

20. Polevaya Y.P., Tyurin V.S., Beletskaya I.P. J. Porphyrins Phthalocyanines 2014, 18, 20-34.

21. (a) Mikhailov K.M., Shelaev I.V., Gostev F.E., Yashchuk Y.P., Tyurin V.S., Beletskaya I.P., Nadtochenko V.A. High Energy Chem. 2014, 48, 276-281; (b) Mikhailov K.M., Shelaev I.V., Gostev F.E., Yashchuk Y.P., Tyurin V.S., Beletskaya I.P., Nadtochenko V.A. Russ. Chem. Bull. 2014, 63, 76-81.

22. (a) Yella A., Lee H.-W., Tsao H.N., Yi C., Chandiran A.K., Nazeeruddin M.K., Diau E.W.-G., Yeh C.-Y., Zakeeruddin S.M., Grätzel M. Science 2011, 334, 629-634; (b) Santhanamoorthi N., Lo C.-M., Jiang J.-C. J. Phys. Chem. Lett. 2013, 4, 524-530.

23. Sharma G.D., Zervaki G.E., Angaridis P.A., Vatikioti A., Gupta K.S.V., Gayathri T., Nagarjuna P., Singh S.P., Chandrasekharam M., Banthiya A., Bhanuprakash K., Petrou A., Coutsolelos A.G. Org. Electron. 2014, 15, 1324-1337.

24. Mikhalitsyna E.A., Tyurin V.S., Beletskaya I.P. J. Porphyrins Phthalocyanine 2015, 19, 874-886.

25. Mikhalitsyna E.A., Tyurin V.S., Zamylatskov I.A., Khrustalev V.N., Beletskaya I.P. Dalton Trans. 2012, 41, 7624-7636.

26. Lindsey J.S., Sreedharan P., Johnson T.E. Tetrahedron 1994, 50, 8941-8968.
27. HyperChem ${ }^{(\mathrm{TM})}$ Professional 7.51, Hypercube, Inc., $1115 \mathrm{NW}$ 4th Street, Gainesville, Florida 32601, USA, 2007.

28. (a) Syrbu S.A., Lubimova T.V., Semeikin A.S. Chem Heterocycl. Compd. 2004, 40, 1262-1270; (b) Kolodina E.A., Lubimova T.V., Syrbu S.A., Semeikin A.S. Macroheterocycles 2009, 2, 33-41.

29. Mikhalitsyna E.A., Tyurin V.S., Nefedov S.E., Syrbu S.A., Semeikin A.S., Koifman O.I., Beletskaya I.P. Eur. J. Inorg. Chem. 2012, 36, 5979-5990.

30. Ryppa C., Senge M.O., Hatscher S.S., Kleinpeter E., Wacker P., Schilde U., Wiehe A. Chem. Eur. J. 2005, 11, 34273443.

31. Lee C.-H., Lindsey J.S. Tetrahedron 1994, 50, 11427-11440.

32. (a) Benjamin L., Miller M.A., Lindsey J.S. J. Org. Chem. 1999, 64, 1391-1396; (b) Benjamin L., Yangzhen C., Lindsey J.S. J. Org. Chem. 1999, 64, 2864-2872.

33. Ranyuk E.R., Filatov M.A., Averin A.D., Cheprakov A.V., Beletskaya I.P. Synthesis 2012, 44, 393-398.

34. Mikhalitsyna E.A., Tyurin V.S., Khrustalev V.N., Lonin I.S., Beletskaya I.P. Dalton Trans. 2014, 43, 3563-3575.

35. Kim Y.H., Jeong D.H., Osuka A. J. Am. Chem. Soc. 2001, 123, 76-86.

36. Cho H.S., Song N.W., Osuka A. J. Phys. Chem. A 2000, 104, 3287-3298.

37. Wook H., Atsuhiro O., Dongho K. J. Am. Chem. Soc. 2004, 126, 16187-16198.

38. Anderson H.L. Inorg. Chem. 1994, 33, 972-981.

Received 21.07.2015

Accepted 15.12.2015 